\title{
Urgency of Maqashid Sharia in Sharia Non-Bank Financial Industry in Indonesia 2016-2018
}

\author{
Budi Sukardi ${ }^{1}$, Supriyanto ${ }^{2}$, Eko Asmanto ${ }^{3}$ \\ budizureydi@gmail.com ${ }^{1}$, supriyanto.mud@gmail.com², ekoasmanto@umsida.ac.id ${ }^{3}$ \\ IAIN Surakarta ${ }^{1,2}$, Universitas Muhammadiyah Sidoarjo ${ }^{3}$
}

\begin{abstract}
The present study aims to delineate the performance and contribution of Maqashid Syariah on the Islamic Non-Bank Financial Industries (IKNB) in Indonesia. This study employed a descriptive quantitative approach by taking several $I K N B$ in Indonesia as the samples, i.e. Islamic finance company, Islamic insurance, Sharia pension funding, and Pawnshop. The data were analyzed by using the Simple Additive Weighting method. The results showed that based on the performance of Maqashid Syariah index of Islamic non-bank financial industries in Indonesia, the DPLK Muamalah was in the first ranking, followed by Reindo Syariah in the second, Takaful Insurance Indonesia in the third, Sarana Multigriya in the fourth, and Pawshop Indonesia in the last. Maqashid Syariah highly contributed to the field of economics, environments and sustainable financial services in responding to the needs of the society and fixed the poverty issues that have not been completely resolved by the government. Therefore, it becomes the pioneer of Sharia economic growth in Indonesia and contributes to the development of human resources. Besides, it is hoped that Maqashid Syariah will be a leading concept of Islamic financial services to achieve the highest objective of the Sharia principle.
\end{abstract}

Keywords: IKNB Syariah, maqashid syariah, simple additive weighting (SAW).

\section{Pendahuluan}

Industri keuangan non bank memiliki peran dalam perekonomian, yaitu pembiayaan, proteksi atas kerugian keuangan, penyertaan modal sementara, investasi, bantuan likuiditas, serta ada sekitar 140 perusahaan IKNB. IKNB Syariah adalah lembaga jasa keuangan yang fokus pada pemenuhan jasa keuangan pada bidang atau aktivitas lembaga asuransi, lembaga dana pensiun, lembaga pembiayaan, dan pada sistem, prosedur dan operasionalnya tidak bertentangan dengan pemenuhan prinsip syariah. Industri keuangan non bank atau biasa disingkat dengan istilah IKNB, terdiri atas asuransi, pembiayaan modal ventura, pegadaian, dana pensiun, lembaga keuangan mikro (LKM), lembaga pembiayaan ekspor Indonesia (LPEI), dan sarana multi infrastruktur (SMI). Industri Keuangan non Bank (IKNB) yaitu lembaga industri keuangan di luar perbankan dan pasar modal yang menawarkan produk keuangan kepada masyarakat dan menarik dana dari masyarakat secara tidak langsung. [1]

Perkembangan industri keuangan syariah secara umum menurun di antara negara-negara Islam lainnya, dikarenakan perbedaan karakteristik pada arah pengembangan keuangan syariah. Di Indonesia pengembangan industri keuangan syariah terfokus pada pasar dalam pemenuhan segala kegiatan masyarakat terutama pada sektor jasa dan perdagangan, sehingga membedakan fokus tersebut pada negara-negara seperti di Malaysia, Iran bahkan Saudi Arabia, dimana mereka fokus dalam pengembangan investasi keuangan serta adanya campur tangan pemerintah pada regulasi dan pengembangan investasi syariah. Walaupun hal ini berdampak signifkan pada pertumbuhan dan 
persaingan antara industri keuangan syariah dan konvensional rata-rata 15 - $30 \%$ setiap tahunnya $[2]$.

Untuk meningkatkan pertumbuhan dan perkembangan prospek industri keuangan syariah di Indonesia, diperlukan sebuah sistem dalam pengukuran kinerja keuangan syariah yang baik dan berkelanjutan dengan melakukan pemantauan yang terukur [3]. Pengukuran terhadap sistem keuangan syariah dilakukan untuk menganalisa tujuan tertinggi industri keuangan syariah dalam melaksanakan fungsinya sebagai lembaga intermediary jasa keuangan terhadap masyarakat Indonesia, dimana saat ini menghadapi banyak tantangan seperti AFTA, MEA, revolusi industri, financial technology, serta agar mampu melakukan perubahan dan adaptasi terhadap kebutuhan pada tatanan sosial dan komunitas pelaku industri dan pasar, keluarga, perusahaan bahkan ikatan sufistik religius masyarakat, sehingga industri keuangan syariah dapat memberikan bukti kepercayaan bagi masyarakat dan meningkatkan hubungan antara para stakeholder [4].

Sampai saat ini, pengukuran kinerja sebuah perusahaan sudah banyak dilakukan oleh para peneliti, akan tetapi pengukuran tersebut masih banyak terfokus pada pengukuran kinerja dari aspek keuangan dengan penggunaan pengukuran kinerja bank, seperti CAMELS, EVA, ROA dan ROE [5]. Walaupun dari sejumlah alat pengukuran kinerja bank yang banyak digunakan masih memiliki kelemahan dimana pengukuran tersebut tidak memperhatikan aspek non keuangan yang sebenarnya sangat memiliki pengaruh dan berdampak kinerja jangka panjang bagi perusahaan [6]. Kebanyakan asumsi menyatakan bahwa faktor non keuangan dalam perusahaan adalah faktor penting dalam menentukan kinerja sebuah perusahaan dalam jangka waktu yang panjang bahkan berkelanjutan (sustainability goals) [7].

Untuk menjaga kepentingan para stakeholder serta meningkatkan kesejahteraan masyarakat yang saat ini terabaikan oleh para investor tingkat ekonomi menengah keatas, maka perlu upaya dalam memberikan perlindungan bagi sosial dan kesejahteraan mereka dengan membuktikan langsung dalam sebuah pengukuran kinerja yang berorientasi pada pemenuhan tujuan tertinggi syariah [8]. Upaya ini dilakukan dengan melakukan pemenuhan terhadap tujuan tertinggi syariah yang dipercaya mampu untuk memberikan kontribusi dan manfaat bagi masyarakat luas [9].

Harapan dari pengukuran tujuan tertinggi syariah (maqashid syariah) supaya bisa memberikan ilustrasi keuangan melalui pendekatan indeks maqashid syariah yang memberikan gambaran kinerja industri keuangan syariah lebih strategis, komprehensif dan menjadi kebijakan umum bagi seluruh industri keuangan syariah khususnya lembaga keuangan syariah non bank di Indonesia.

Kasus-kasus keuangan syariah secara umum di Indonesia banyak sekali terjadi, seperti kasus money laundry, penggelapan dana nasabah, pelanggaran terhadap norma dan etika perusahaan serta mengabaikan aspek sosial perusahaan bagi masyarakat. Perihal ini menjadi tolak ukur dalam pemenuhan indeks pada kriteria pemenuhan dalam maqashid syariah, dimana banyak penelitian terkait maqashid syariah masih mengabaikan faktor sosial, lingkungan serta ekonomi pada masyarakat [10]. Seharusnya faktor sosial, lingkungan dan ekonomi merupakan faktor yang dikembangkan dalam pemenuhan dan pengembangan maqashid syariah, hal ini disebabkan oleh karena dimensi dalam maqashid syariah memiliki orientasi pada keberlangsungan kehidupan manusia serta mampu memberikan rancang bangun bisnis keuangan syariah secara jangka panjang.

Saat menghadapi persaingan global ekonomi dan keuangan, industri keuangan syariah khususnya industri keuangan syariah non bank belum bisa memberikan andil dalam peningkatan kesejahteraan masyarakat secara umum, melakukan kerjasama dan investasi yang mutual (competition-competitive-mutual), mengurangi ketimpangan kemiskinan dan kesejahteraan masyarakat serta memajukan nilai-nilai peradaban Islam serta menjaga peradaban tersebut agar sesuai dengan zaman. Bahkan ironis, industri keuangan syariah di Indonesia belum dapat menciptakan suasana berkeadilan pada masyarakat pada aspek soaial dimana pemenuhan terhadap aspek maqashid syariah sangat rendah dan belum berorientasi pada pencapaian kesejahteraan dan 
kebahagiaan dunia akhirat, akan tetapi masih terfokus pada aspek keuntungan (profit) bahkan laba maksimum, juga rendahnya pencapaian pada perolehan ekonomi nasional di Indonesia walaupun secara global Indoensia memili kinerja yang baik pada industri keuangan syariah secara umum.

Berdasarkan permasalahan di atas, maka dalam melakukan analisa akan pentingnya tujuan tertinggi syariah, segala aspek dan manfaatnya bagi industri keuangan syariah khususnya lembaga keuangan non bank syariah di Indonesia, peneliti tertarik untuk melakukan eksplorasi serta identifikasi terhadap manifestasi tujuan dan manfaat industri keuangan non bank syariah di Indonesia serta kontribusi nilai-nilai maqashid syariah terhadap pembangunan berkelanjutan industri keuangan non bank syariah di Indonesia. Adapun kajian permasalahan yang akan dilakukan yaitu bagaimana kinerja Industri keuangan non bank syariah di Indonesia diukur dengan kriteria maqashid syariah, serta bagaimana kontribusi inklusif maqashid shariah terhadap Industri keuangan non bank syariah di Indonesia?

\section{Metode}

Objek penelitian yaitu perusahaan asuransi syariah, perusahaan pembiayaan syariah, perusahaan modal ventura syariah, perusahaan pembiayaan infrastruktur syariah, dana pensiun syariah, perusahaan penjaminan syariah, perusahaan pegadaian, lembaga pembiayaan ekspor Indonesia, lembaga keuangan mikro syariah. Data yang digunakan bersumber dari data sekunder yang diperoleh dari laporan keuangan tahunan (annual report), laporan Good Corporate Governance (GCG) tahun 2015-2018, yang dipublikasi oleh OJK serta data-data pendukung lainnya seperti laporan kegiatan sosial industri keuangan syariah. Adapun data primer diperoleh dari para ahli perbankan syariah (DPS, MUI, MES, IAEI) dan pengambil kebijakan (BI, OJK, Kemenkeu) di industri keuangan non bank syariah melalui wawancara atau FGD (focus group discussion).

Untuk menjawab permaslahan pengukuran kriteria maqashid syariah di Indonesia, peneliti mengadopsi metode simple additive weighting (SAW) atau dikenal juga dengan istilah metode penjumlahan terbobot. Konsep dasar metode SAW adalah mencari penjumlahan terbobot dari rating kinerja pada setiap alternatif semua atribut [11], [12]. Metode SAW membutuhkan proses normalisasi matriks keputusan (x) ke suatu skala yang dapat diperbandingkan dengan semua rating alternatif yang ada. Metode SAW ini mengharuskan pembuat keputusan menentukan bobot setiap atribut. Skor total untuk alternatif diperoleh dengan menjumlahkan seluruh hasil perkalian antara rating dan bobot tiap atribut. Rating tiap atribut haruslah bebas dimensi dalam arti telah melewati proses normalisasi matriks sebelumnya [13]. Adapun formula untuk melakukan normalisasi, yaitu

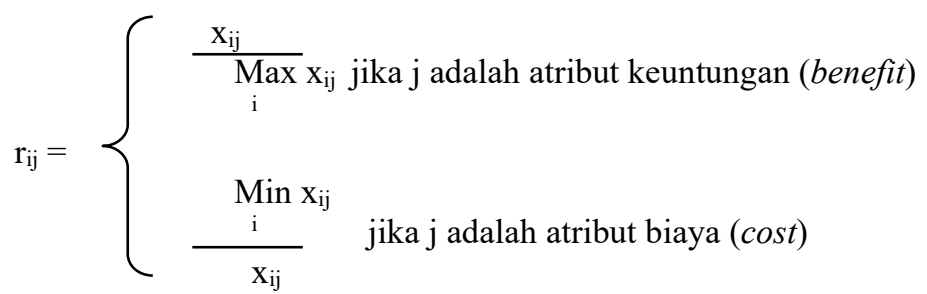

Dengan $r_{i j}$ adalah rating kinerja ternormalisasi dari alternatif $A_{i}$ pada atribut $C_{j} ; i=1,2, \ldots, m$ dan $\mathrm{j}=1,2, \ldots, n$. Nilai preferensi untuk setiap alternatif $\left(\mathrm{V}_{\mathrm{i}}\right)$ diberikan sebagai: 


$$
\mathrm{V}_{\mathrm{i}}=\sum_{j=1}^{n} \mathrm{w}_{\mathrm{j}} \mathrm{r}_{\mathrm{ij}}
$$

Nilai $V_{i}$ yang lebih besar mengindikasikan bahwa alternatif $A_{i}$ lebih terpilih. Sementara untuk menjawab rumusan permasalahan kedua dan ketiga, peneliti melakukan langkah-langkah analisis data sebagai berikut?

\section{Pembahasan}

Industri keuangan non bank syariah atau lebih dikenal dengan istilah IKNB syariah merupakan bagian dari dasar perekonomian yang mampu memberikan pencapaian pada roda perkonomian Islami secara nasional di Indonesia. Aktivitas operasional dan aktivitas jasa IKNB syariah mencakup di bidang jasa asuransi, dana pensiun, lembaga jasa keuangan dan infrastruktur pembiayaan syariah dimana sistem, prosedurnya terikat dengan prinsip-prinsip syariah (Islami).

Secara garis besar kegiatan dan aktivitas jasa keuangan ini berbeda dengan IKNB pada lembaga konvensional pada aspek produk dan transaksi serta perikatan (akad) produk. Adapun ilustrasi terhadap IKNB syariah di Indonesia dapat dilihat pada tabel sebagai berikut :

Tabel 1. Overview IKNB Syariah Mei 2019

\begin{tabular}{|c|c|c|c|c|c|c|c|}
\hline Keterangan & $\begin{array}{c}\text { Jumlah } \\
\text { Industri } \\
\text { Syariah } \\
\text { (Unit) }\end{array}$ & $\begin{array}{c}\text { Jumlah } \\
\text { Perusahaan } \\
\text { Paket Investasi } \\
\text { Syariah / Unit } \\
\text { Usaha Syariah }\end{array}$ & $\begin{array}{c}\text { Aset } \\
\text { (Miliar } \\
\text { Rp) }\end{array}$ & $\begin{array}{c}\text { Kewajiban } \\
\text { (Miliar Rp) }\end{array}$ & $\begin{array}{c}\text { Dana } \\
\text { Syirkah } \\
\text { Temporer } \\
\text { (Miliar Rp) }\end{array}$ & $\begin{array}{c}\text { Ekuitas } \\
\text { (Miliar } \\
\text { Rp) }\end{array}$ & $\begin{array}{c}\text { Aset } \\
\text { Produktif } \\
\text { (Miliar Rp) }\end{array}$ \\
\hline
\end{tabular}

\begin{tabular}{|c|c|c|c|c|c|c|c|c|}
\hline $\begin{array}{l}\text { 1. Asuransi } \\
\text { Syariah } \\
\text { a. Asurans }\end{array}$ & 13 & 49 & 42.280 & 7.809 & - & 34.391 & 37.102 & $\begin{array}{l}\text { 1. Sharia } \\
\text { Insurance }\end{array}$ \\
\hline $\begin{array}{l}\text { i Jiwa } \\
\text { Syariah } \\
\quad \text { b. Asurans }\end{array}$ & 7 & 23 & 34.724 & 4.412 & - & 30.302 & 31.951 & $\begin{array}{l}\text { a. Sharia Life } \\
\text { Insurance }\end{array}$ \\
\hline $\begin{array}{l}\text { i Umum } \\
\text { Syariah } \\
\text { c. }\end{array}$ & 5 & 24 & 5.666 & 2.574 & - & 3.091 & 3.802 & $\begin{array}{l}\text { b. Sharia Non- } \\
\text { Life Insurance }\end{array}$ \\
\hline $\begin{array}{l}\text { Reasuransi } \\
\text { Syariah } \\
\text { 2. Lembaga }\end{array}$ & 1 & 2 & 1.891 & 823 & - & 997 & 1.349 & $\begin{array}{c}\text { c. Sharia } \\
\text { Reinsurance }\end{array}$ \\
\hline $\begin{array}{l}\text { Pembiayaan } \\
\text { Syariah } \\
\quad \text { a. }\end{array}$ & 8 & 34 & 26.587 & 18.559 & 2.000 & 6.027 & 22.486 & $\begin{array}{l}\text { 2. Sharia Finance } \\
\text { Institutions } \\
\text { a. Sharia }\end{array}$ \\
\hline Perusahaan & 4 & 31 & 21.073 & 15.487 & - & 5.586 & 17.955 & Finance Company \\
\hline
\end{tabular}




\begin{tabular}{|c|c|c|c|c|c|c|c|c|}
\hline $\begin{array}{l}\text { Pembiayaan } \\
\text { Syariah } \\
\text { b. } \\
\text { Perusahaan }\end{array}$ & & & & & & & & \\
\hline $\begin{array}{l}\text { Modal } \\
\text { Ventura }\end{array}$ & & & 2.124 & 1.822 & - & 302 & 1.822 & $\begin{array}{l}\text { b. Sharia } \\
\text { Venture Capital }\end{array}$ \\
\hline $\begin{array}{l}\text { Syariah } \\
\text { c. }\end{array}$ & 4 & 2 & & & & & & Company \\
\hline Perusahaan & & & & & & & & \\
\hline $\begin{array}{l}\text { Pembiayaan } \\
\text { Infrastruktu }\end{array}$ & & & 3.389 & 1.250 & 2.000 & 140 & 2.710 & $\begin{array}{c}\text { c. Sharia } \\
\text { Infrastructure }\end{array}$ \\
\hline $\begin{array}{l}\text { r Syariah } \\
\text { 3, Dana }\end{array}$ & - & 1 & & & & & & $\begin{array}{l}\text { Finance Company } \\
\text { 3. Sharia Pensiun }\end{array}$ \\
\hline $\begin{array}{l}\text { Pensiun } \\
\text { a. DPPK- }\end{array}$ & 3 & 3 & 4.211 & 4.211 & - & - & 4.173 & Fund \\
\hline $\begin{array}{l}\text { PPMP } \\
\text { Syariah } \\
\quad \text { b. DPPK- }\end{array}$ & 1 & - & 576 & 576 & - & - & 573 & a. EPF-DBPF \\
\hline $\begin{array}{l}\text { PPIP } \\
\text { Syariah } \\
\text { c. DPLK }\end{array}$ & 1 & - & 117 & 117 & - & - & 116 & b. EPF-DCPF \\
\hline $\begin{array}{l}\text { Syariah } \\
\text { 4. Lembaga }\end{array}$ & 1 & 3 & 3.518 & 3.518 & - & - & 3.484 & c. FIPF \\
\hline Jasa & & & & & & & & 3.Sharia \\
\hline $\begin{array}{l}\text { Keuangan } \\
\text { Khusus }\end{array}$ & & & & & & & & $\begin{array}{l}\text { Spesialized } \\
\text { Financial }\end{array}$ \\
\hline $\begin{array}{l}\text { Syariah } \\
\text { a. }\end{array}$ & 8 & 7 & 27.103 & 21.615 & 500 & 5.661 & 2.434 & $\begin{array}{l}\text { Institution } \\
\text { a. Sharia }\end{array}$ \\
\hline $\begin{array}{l}\text { Penjaminan } \\
\text { Syariah } \\
\text { b. LPEI }\end{array}$ & 2 & 4 & 1.555 & 767 & - & 789 & 879 & $\begin{array}{l}\text { Guarantee } \\
\text { Company } \\
\quad \text { b. LPEI Sharia }\end{array}$ \\
\hline $\begin{array}{l}\text { Syariah } \\
\text { c. }\end{array}$ & 6 & 1 & 8.894 & 6.061 & - & 2.834 & - & Unit \\
\hline $\begin{array}{l}\text { Pergadaian } \\
\text { Syariah } \\
\quad \text { d. }\end{array}$ & - & 1 & 14.603 & 13.349 & - & 1.926 & $\mathbf{0}$ & $\begin{array}{l}\text { c. Sharia Pawn } \\
\text { Shop }\end{array}$ \\
\hline Perusahaan & & & & & & & & \\
\hline Pembiayaan & & & & & & & & d. Sharia \\
\hline $\begin{array}{l}\text { Sekunder } \\
\text { Perumahan } \\
\text { (PPSP) }\end{array}$ & & & 2.050 & 1.438 & 500 & 112 & 1.555 & $\begin{array}{l}\text { Housing } \\
\text { Secondary } \\
\text { Financing }\end{array}$ \\
\hline Syariah & - & 1 & & & & & & Company \\
\hline 5. Lembaga & & & & & & & & \\
\hline Keuangan & & & & & & & & 4. Sharia Micro \\
\hline Mikro & & & 346 & & & & 77 & Finance \\
\hline $\begin{array}{l}\text { Syariah } \\
\text { 6. Finansial }\end{array}$ & 65 & - & & 48 & 115 & 184 & & Institution \\
\hline Teknologi & 6 & 1 & - & - & - & - & - & \\
\hline$J U M L A H$ & 103 & 94 & $\begin{array}{r}100.52 \\
6\end{array}$ & 52.241 & 2.615 & 46.262 & 66.272 & TOTAL \\
\hline
\end{tabular}

Adapun langkah awal yang dilakukan adalah dengan menghitung persentase setiap rasio kinerja maqashid syariah index. Setiap rasio tersebut mewakili tiga indikator kinerja yaitu educating individu, establishing justice dan public interest. Data penelitian ini diperoleh dari laporan tahunan IKNB Syariah (Asuransi Takaful, Pegadaian, DPLK Muamalah, PT. Reindo Syariah dan PT Sarana Multigriya Finansial (Persero). Data diperoleh dari tahun 2016-2018 baik dari laporan manajemen, 
annual report maupun dari laporan keuangan tahunan. Adapun persentase setiap rasio kinerja maqashid sharia index IKNB syariah adalah sebagai berikut.

\section{Rasio Kinerja Maqashid Syariah Index Asuransi Takaful Indonesia}

Adapun rasio kinerja MSI Asuransi Takaful Indonesia dari tahun 2015 sampai dengan tahun 2018 dapat dilihat pada tabel di bawah ini :

Tabel 2 Rasio Kinerja Asuransi Takaful Indonesia Berdasarkan Indeks Maqashid Syariah Tahun 2016 - 2018

\begin{tabular}{|c|c|c|c|}
\hline Rasio & 2016 & 2017 & 2018 \\
\hline R1.1 & $\mathbf{0 , 0 0}$ & $\mathbf{0 , 0 0}$ & $\mathbf{0 , 0 0}$ \\
\hline R1.2 & $\mathbf{0 , 0 0}$ & $\mathbf{0 , 0 0}$ & $\mathbf{0 , 0 0}$ \\
\hline R1.3 & $\mathbf{0 , 0 0}$ & $\mathbf{0 , 0 0}$ & $\mathbf{0 , 0 0}$ \\
\hline R1.4 & 2,21 & $\mathbf{0 , 0 0}$ & $\mathbf{0 , 0 0}$ \\
\hline R2.1 & 31,77 & 47,64 & 56,18 \\
\hline R2.2 & $\mathbf{0 , 0 0}$ & $\mathbf{0 , 0 0}$ & $\mathbf{0 , 0 0}$ \\
\hline R2.3 & 100,00 & 100,00 & 100,00 \\
\hline R3.1 & 1,01 & 1,17 & 0,78 \\
\hline R3.2 & 6,04 & 3,14 & 2,03 \\
\hline R.3.3 & 21,29 & 17,21 & 16,63 \\
\hline
\end{tabular}

Pada dimensi pendidikan, Asuransi Takaful Indonesia belum menyelenggarakan hibah, beasiswa, pendidikan dan pelatihan, dan penelitian terkait takaful. Pada tahun 2016 hanya melakukan publikasi dan promosi terhadap Asuransi Takaful sebagai wujud memberikan kesadaran masyarakat.

Pada dimensi keadilan, di Asuransi Takaful, belum dilakukan pembiayaan dalam bentuk bagi hasil maupun perkongsian. Akan tetapi dari data tahun 2016 sampai dengan 2018, asuransi Takaful memperoleh pendapatan yang halal dari seluruh jumlah pendapatan yang diterima selama tahun tersebut.

Pada dimensi kepentingan publik, asuransi takaful sudah melakukan investasi dan pelayanan sosial dalam rangka pemenuhan kepentingan publik dan menyejahterakan sosial masyarakat.

\section{Rasio Kinerja Maqashid Syariah Index Pegadaian Indonesia}

Adapun rasio kinerja MSI Pegadaian Indonesia dari tahun 2015 sampai dengan tahun 2018 dapat dilihat pada tabel sebagai berikut : 
Tabel 3 Rasio Kinerja Pegadaian Indonesia Berdasarkan Indeks Maqashid Syariah Tahun $2016-2018$

\begin{tabular}{|c|c|c|c|}
\hline Rasio & 2016 & 2017 & 2018 \\
\hline R1.1 & 0,03 & 0,05 & 0,11 \\
\hline R1.2 & $\mathbf{0 , 0 0}$ & $\mathbf{0 , 0 0}$ & $\mathbf{0 , 0 0}$ \\
\hline R1.3 & 0,61 & 0,65 & 1,46 \\
\hline R1.4 & 3,23 & 2,74 & 2,36 \\
\hline R2.1 & 17,17 & $\mathbf{8 , 5 7}$ & 6,05 \\
\hline $\mathrm{R} 2.2$ & $\mathbf{0 , 0 0}$ & 0,00 & $\mathbf{0 , 0 0}$ \\
\hline $\mathbf{R 2 . 3}$ & 100,00 & 100,00 & 100,00 \\
\hline R3.1 & 4,72 & 5,16 & 5,26 \\
\hline R3.2 & $\mathbf{0 , 0 0}$ & 0,00 & 0,00 \\
\hline R.3.3 & 2,74 & 3,63 & 2,15 \\
\hline
\end{tabular}

Pada dimensi pendidikan, pegadaian sudah menyelenggarakan hibah, beasiswa, pendidikan, dan pelatihan sebagai bentuk upgrade kompetensi para karyawan, tetapi belum melakukan penelitian terkait pegadaian. Pada tahun 2016 sampai dengan 2018, juga sudah melakukan publikasi dan promosi terhadap pegadaian sebagai wujud memberikan kesadaran masyarakat akan pentingnya pegadaian dalam memberikan solusi penyelesaian permasalahan keuangan.

Pada dimensi keadilan di pegadaian, belum dilakukan pembiayaan dalam bentuk bagi hasil maupun perkongsian. Akan tetapi dari data tahun 2016 sampai dengan 2018, pegadaian memperoleh pendapatan yang halal dari seluruh jumlah pendapatan yang diterima selama tahun tersebut.

Pada dimensi kepentingan publik, pegadaian sudah melakukan investasi dan pelayanan sosial dalam rangka pemenuhan kepentingan publik dan menyejahterakan sosial masyarakat, hanya belum memberikan dana sosial dalam bentuk zakat kepada masyarakat.

\section{Rasio Kinerja Maqashid Syariah Index DPLK Muamalah Indonesia}

Adapun rasio kinerja MSI DPLK Muamalah Indonesia dari tahun 2015 sampai dengan tahun 2018 dapat dilihat pada tabel di bawah ini :

Tabel 4 Rasio Kinerja DPLK Muamalah Indonesia Berdasarkan Indeks Maqashid Syariah Tahun 2016 - 2018

\begin{tabular}{cccc}
\hline Rasio & 2016 & 2017 & 2018 \\
\hline R1.1 & 0,00 & 0,00 & 0,00
\end{tabular}




\begin{tabular}{|c|c|c|c|}
\hline R1.2 & 0,00 & 0,00 & 0,00 \\
\hline R1.3 & $\mathbf{0 , 0 0}$ & $\mathbf{0 , 0 0}$ & $\mathbf{0 , 0 0}$ \\
\hline R1.4 & $\mathbf{0 , 0 0}$ & $\mathbf{0 , 0 0}$ & $\mathbf{0 , 0 0}$ \\
\hline R2.1 & 1,79 & 25,85 & 29,99 \\
\hline R2.2 & $\mathbf{0 , 0 0}$ & $\mathbf{0 , 0 0}$ & $\mathbf{0 , 0 0}$ \\
\hline R2.3 & 100,00 & 100,00 & 100,00 \\
\hline R3.1 & 5,43 & 4,72 & 5,47 \\
\hline R3.2 & $\mathbf{0 , 0 0}$ & $\mathbf{0 , 0 0}$ & $\mathbf{0 , 0 0}$ \\
\hline R.3.3 & 99,87 & 98,46 & 102,00 \\
\hline
\end{tabular}

Pada dimensi pendidikan, DPLK Muamalah belum menyelenggarakan hibah, beasiswa, pendidikan dan pelatihan, penelitian bagi karyawan, bahkan belum melakukan publikasi dan promosi terhadap DPLK Muamalah sebagai wujud memberikan kesadaran masyarakat. Namun, dimungkinkan promosi dan iklan tersebut bahkan upgrade kompetensi karyawan digabungkan dengan peningkatan kompetensi yang dilakukan di Bank Muamalah Indonesia.

Pada dimensi Keadilan di DPLK Muamalah, belum dilakukan pembiayaan dalam bentuk bagi hasil maupun perkongsian. Akan tetapi dari data tahun 2016 sampai dengan 2018, DPLK Muamalah memperoleh pendapatan yang halal dari seluruh jumlah pendapatan yang diterima selama tahun tersebut.

Pada dimensi kepentingan publik, DPLK Muamalah ? sudah melakukan investasi dan pelayanan sosial dalam rangka pemenuhan kepentingan publik dan mensejahterakan sosial masyarakat.

\section{Rasio Kinerja Maqashid Syariah Index PT Reindo Syariah Indonesia}

Adapun rasio kinerja MSI PT Reindo Syariah Indonesia dari tahun 2015 sampai dengan tahun 2018 adalah sebagai berikut :

Tabel 5 Rasio Kinerja PT. Reindo Syariah Indonesia Berdasarkan Indeks Maqashid Syariah Tahun 2016 - 2018

\begin{tabular}{cccc}
\hline Rasio & 2016 & 2017 & 2018 \\
\hline R1.1 & 0,00 & 0,00 & 0,00 \\
R1.2 & 0,00 & 0,00 & 0,00
\end{tabular}




\begin{tabular}{|c|c|c|c|}
\hline R1.3 & 0,00 & 0,00 & 0,00 \\
\hline R1.4 & 11,01 & 7,25 & 6,77 \\
\hline R2.1 & 0,00 & $\mathbf{0 , 0 0}$ & $\mathbf{0 , 0 0}$ \\
\hline R2.2 & 0,00 & 0,00 & $\mathbf{0 , 0 0}$ \\
\hline R2.3 & 100,00 & 100,00 & 100,00 \\
\hline R3.1 & 3,69 & 5,45 & 3,49 \\
\hline R3.2 & 26,06 & 16,48 & 9,47 \\
\hline R.3.3 & 69,87 & 71,46 & 75,41 \\
\hline
\end{tabular}

Pada dimensi Pendidikan, PT Reindo Syariah Indonesia belum menyelenggarakan hibah, beasiswa, pendidikan dan pelatihan, penelitian bagi karyawan Reindo Syariah. Namun pada tahun 2016 sampai dengan 2018 sudah melakukan publikasi dan promosi terhadap Reindo Syariah, yaitu perusahaan Reasuransi, sebagai wujud memberikan kesadaran masyarakat.

Pada dimensi keadilan, di PT Reindo Syariah belum dilakukan pembiayaan dalam bentuk bagi hasil maupun perkongsian dan belum melakukan pencadangan terhadap pendapatan keuntungan yang belum dibagikan kepada nasabah dari selisih kekurangan pembagian profit. Akan tetapi, dari data tahun 2016 sampai dengan 2018, asuransi ? PT Reindo memperoleh pendapatan yang halal dari seluruh jumlah pendapatan yang diterima selama tahun tersebut.

Pada dimensi kepentingan publik, asuransi ? PT Reindo sudah melakukan investasi dan pelayanan sosial dalam rangka pemenuhan kepentingan publik dan mensejahterakan sosial masyarakat.

\section{Rasio Kinerja Maqashid Syariah Index PT. Sarana Multigriya Finansial (Persero)} Indonesia

Adapun rasio kinerja MSI PT. Sarana Multigriya Finansial (Persero)Indonesia dari tahun 2015 sampai dengan tahun 2018 dapat dilihat pada tabel di bawah ini :

Tabel 6 Rasio Kinerja PT. Sarana Multigriya Finansial (Persero) Indonesia Berdasarkan Indeks Maqashid Syariah Tahun 2016 - 2018

\begin{tabular}{cccc}
\hline Rasio & 2016 & 2017 & 2018 \\
\hline R1.1 & 0,02 & 0,02 & 0,29 \\
R1.2 & 0,00 & 0,34 & 0,34 \\
& 0,14 & 0,34 & 0,50
\end{tabular}




\begin{tabular}{|c|c|c|c|}
\hline R1.4 & 1,23 & 1,58 & 1,39 \\
\hline R2.1 & 0,64 & 0,69 & 0,76 \\
\hline R2.2 & 2,08 & 1,74 & 1,72 \\
\hline R2.3 & 100,00 & 100,00 & 100,00 \\
\hline R3.1 & 2,42 & 2,54 & 2,24 \\
\hline R3.2 & 0,02 & 0,04 & 0,20 \\
\hline R.3.3 & 63,41 & 70,89 & 78,88 \\
\hline
\end{tabular}

Pada dimensi pendidikan, PT Sarana Multigriya Finansial sudah menyelenggarakan hibah, beasiswa, pendidikan dan pelatihan, penelitian terkait PT Sarana Multigriya Finansial bagi karyawan, pada tahun 2016 sampai dengan tahun 2018 sudah melakukan publikasi dan promosi terhadap pada masyarakat sebagai wujud memberikan kesadaran masyarakat.

Pada dimensi keadilan di PT Sarana Multigriya Finansial sudah dilakukan pembiayaan dalam bentuk bagi hasil maupun perkongsian. Data tahun 2016 sampai dengan 2018, PT Sarana Multigriya Finansial memperoleh pendapatan yang halal dari seluruh jumlah pendapatan yang diterima selama tahun tersebut.

Pada dimensi kepentingan publik, PT. Sarana Multigriya Finansial sudah melakukan investasi dan pelayanan sosial dalam rangka pemenuhan kepentingan publik dan mensejahterakan sosial masyarakat.

6. Perhitungan Bobot Maqashid Syariah Index Industri Keuangan Non Bank Syariah Adapun perhitungan Bobot Maqashid Syariah Index IKNB Syariah dapat dilihat pada tabel

Tabel 7 Kinerja Industri Keuangan Non Bank Syariah Indonesia Berdasarkan MasingMasing Indikator Kinerja Indeks Maqashid Syariah Tahun 2016-2018 (\%)

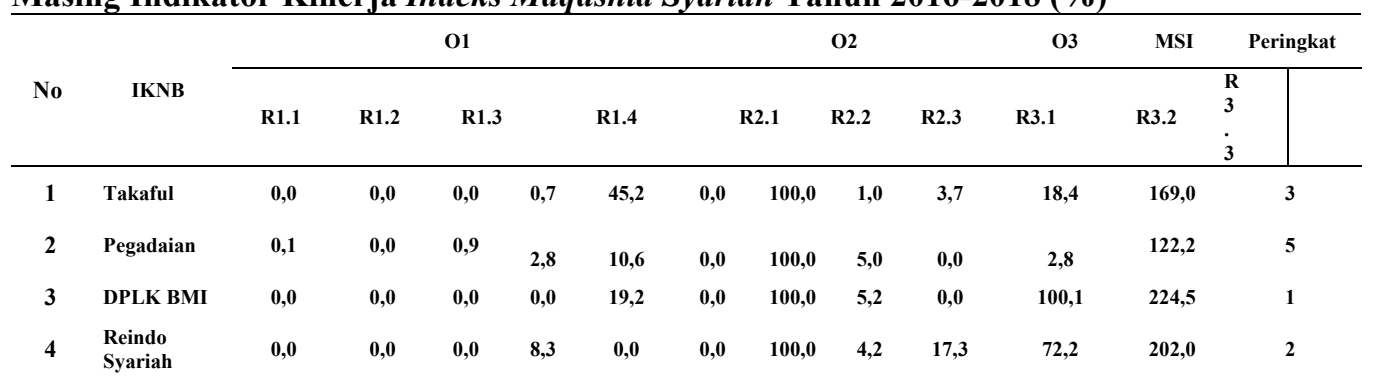


Pada tabel di atas, menunjukkan bahwa kinerja Indeks Maqashid Syariah, peringkat tertinggi yaitu DPLK Muamalah, peringkat kedua yaitu PT Reindo Syariah (Perusahaan Reasuransi), peringkat ketiga Asuransi Takaful Indonesia, peringkat keempat yaitu PT Sarana Multigriya Finansial (Perusahaan Pembiayaan Sekunder), dan peringkat terakhir yaitu Pegadaian Indonesia.

\section{Kontribusi Inklusif Maqashid Shariah terhadap Pembangunan Berkelanjutan Industri Keuangan Non Bank (IKNB) Syariah di Indonesia}

Nilai-nilai maqashid syariah merupakan bagian dari kerangka filosofis dasar dalam aktivitas ekonomi sosial yang muncul sebagai revolusi dan resolusi dalam pencapaian akses kebutuhan masyarakat di bidang keuangan khususnya dan perekonomian serta perdagangan secara umum. Hal ini adalah menjadi solusi dalam memberikan akses kepada masyarakat miskin yang termarjinalkan serta tergerus dengan modal dan investasi terhadap jasa keuangan dan lembaga sosial.

Islam telah menjelaskan adanya konsep risk sharing dan redistribution of wealth, dimana konsep ini merupakan perlawanan keadilan terhadap industri keuangan konvensional yang sepenuhnya memberikan perhatian maksimal terhadap pencapaian kesejahteraan masyarakat melalui prinsip keadilan dan tanggung jawab sosial dalam setiap transaksi dan investasi. Akan tetapi, konsep industri keuangan konvensioanl yang hanya berorientasi pada keuntungan dan pemodal besar merugikan roda perekonmian nasional dan tidak mampu mengimbangi gejolak krisis keuangan dunia yang berdampak pada penurunan nilai investasi dan meningkatnya harga komoditas perdagangan.

Keberadaan maqashid syariah sebagai puncak dari segala tujuan aktivitas ekonomi dan keuangan memberikan andil besar dalam sebuah nilai-nilai sosial dan peningkatan pendapatan serta relevan dengan peradaban dan zaman memiliki kontribusi dalam kesejahteraan sosial masyarakat. Tidak dapat dipungkiri, keberadaan maqashid syariah mampu menjadi pertimbangan lembaga keuangan syariah untuk memberikan kepercayaan masyarakat dalam mengakses jasa keuangan melalui literasi keuangan dan peningkatan pendapatan perekonmian keluarga serta membangun pondasi perkonomian yang damai, aman dan sejahtera.

Ketika lembaga keuangan konvensional mengalami kendala permasalahan terhadap tingginya biaya transaksi, kegagalan pengembalian kredit atau pinjaman, maka nilai-nilai maqashid syariah menjadi bukti dalam memberikan solusi terhadap kegagalan-kegagalan sistem keuangan konvensional. Hal ini dapat dilihat dari capaian tingkat investasi dan modal infrastruktur lembaga pembiayaan syariah di Indonesia, dimana lembaga pembiayaan syariah mampu memberikan solusi bagi masyarakat miskin yang tidak terjamah oleh lembaga keuangan konvensional dalam pemenuhan pinjaman mikro dan perumahan serta pinjaman sosial kebajikan.

Wujud dari pemenuhan nilai-nilai maqashid syariah dapat dilihat dari kreatifitas kehidupan masyarakat dalam memenuhi kebutuhan ekonomi di tengah krisis keuangan yang terjadi, masyarakat miskin mampu eksis dan mempertahankan kehidupan serta menjaga keberlangsungan kehidupan ekonomi, sosial dan lingkungan serta menjaganya. Ketercapaian ini menjadi bukti bahwasannya industri keuangan non bank syariah dengan segala pemenuhan nilai-nilai dan capaian maqashid syariah mampu eksis dan bertahan menjadi garda terdepan dalam mengurangi serta memperbaiki kemiskinan struktural di Indonesia, serta memberikan layanan produk yang sesuai dengan kebutuhan masyarakat juga relevan dengan peradaban, zaman dan agama dengan segala ikatan sufistik religi yang melekat pada aktivitas ekonomi, investasi, keuangan dan perdagangan. 


\section{Kesimpulan}

Kinerja industri keuangan non bank syariah di Indonesia berdasarkan pemenuhan kriteria maqashid syariah yaitu peringkat tertinggi DPLK Muamalah, kemudian peringkat kedua yaitu PT. Reindo Syariah (Perusahaan Reasuransi), peringkat ketiga Asuransi Takaful Indonesia, peringkat keempat yaitu PT. Sarana Multigriya Finansial (Perusahaan Pembiayaan Sekunder) dan peringkat terakhir yaitu Pegadaian Indonesia. Adapun kontribusi inklusif maqashid shariah terhadap Industri keuangan non bank syariah di Indonesia yaitu mampu memberikan solusi dan kiprah pada setiap aktivitas ekonomi, sosial, lingkungan secara penuh sebagai pertanggungjawaban individu lembaga dan kepada Allah SWT, hal ini sebagai upaya dalam mengurangi kemiskinan struktural serta perbaikan kesejahteraan masyarakat di Indoesia, sehingga keberadaan IKNB syariah dalam pemenuhan nilai-nilai maqashid syariah selalu fokus pada keberlangsungan hidup lingkungan, alam, sumber daya ekonomi baik itu material dan inmaterial serta kebutuhan manusia.

\section{References}

[1] M. Moch, Direktur Industri Keuangan Non Bank (IKNB) Syariah OJK Moch Muchlasin, penjelasan disampaikan pada Nangkring dan Buka Puasa bareng OJK "Saatnya Lebih Dekat dengan Keuangan Syariah" bertujuan mengenal lebih dekat blogger. Event yang dilaksanakan pada 18 Juni 2017 di Double Tree Cikini. Kompas.com.

[2] M. S. Antonio, Y. D. Sanrego, dan M. Taufiq, "An Analysis of Islamic Banking Performance: Maqashid Index Implementation in Indonesia and Jordania," J. Islam. Finance, vol. 1, no. 1, ISSN 2289-2117 (O) / 2289-2109 (P), 2012.

[3] M. Kuppusamy, A. S. dan S. Saleha, dan Ananda, "Measurement of Islamic Banks Performance Using a Shariah Conformity and Profitablity Model," J. Rev. Islam. Econ., 2010.

[4] M. U. dan H. A. Chapra, "Corporate Governance Lembaga Keuangan Syariah, terj," dalam Oleh Ikhwan Abidin Basri, Jakarta: Bumi Aksara, 2008.

[5] J. P. Bonin, I. Hasan, dan P. Watchtel, "Bank Performance, Efficiency and Ownership in Transition Countries,” J. Bank. Finance, vol. 29, 2005.

[6] N. Y. Seçme, A. Bayrakdaroğlu, dan C. Kahraman, Fuzzy Performance Evaluation In Turkish Banking Sector Using Analytic Hirerarchy Process And Topsis. Expert, 2009.

[7] M. M. Hussein dan Z. Hoque, "Understanding Non-Financial Performance Measurement Practices In Japanese Banks, Accounting," Audit. Account. J., vol. 15, no. 2, 2002.

[8] S. Yuwono, Petunjuk Praktis Penyusunan Balance Scorecard Menuju Organisasi yang Berfokus pada Strategi. Jakarta: PT Gramedia Pustaka Utama, 2004.

[9] D. dan T. Mohammed, "The Performance Measures of Islamic Banking Based on the Maqashid Framework," dalam Paper of IIUM International Accounting Conference INTAC IV, 2008.

[10] S. H. Siddiqui, "Islamic Banking: True Models of Financing," New Horiz., vol. 109, 2001.

[11] P. C. Fishburn, A Problem-Based Selection of Multi-Attribute Decision Making Methods. New Jersey: Blackwell Publisihing, 1967.

[12] K. R. MacCrimmon, Decision Making among Multiple Atribut Alternatives: A Survey and Consolidated Approach. 1968.

[13] S. Kusumadewi dan S. Hartati, Agus Harjoko, Retantyo Wardoyo, Fuzzy Multi-Attribute Decision Making (Fuzzy MADM. Yogyakarta: Graha Ilmu, 2006. 